Kyrylenko O. $N$.

Doctor of Economics, Associate Professor, National Aviation University, Ukraine; e-mail: ons@ua.fm; ORCID ID: 0000-0003-2406-7050

Razumova E. N

Doctor of Economics, Associate Professor, National Aviation University, Ukraine; e-mail: krazum@ukr.net; ORCID ID: 0000-0001-6385-2823

Novak $V . O$.

Ph. D. in Economics, Professor, National Aviation University, Ukraine; e-mail: novak.nau@mail.ru; ORCID ID: 0000-0001-6899-2016

Razanovska $\mathbf{V} . \mathbf{V}$. Assistant, National Aviation University, Ukraine; e-mail: ryazanovskaya@ukr.net; ORCID ID: 0000-0003-2680-3306

\title{
FORECASTING CARGO DEPARTURE BY RAILWAY TRANSPORT TAKING INTO ACCOUNT ECONOMIC CHANGES IN UKRAINE
}

Abstract. The article analyzes the forecast of transportation of coal by rail (as a cargo with the most specific weight in the structure of transportation) with the help of the proposed autoregressive model of growth, taking into account economic changes in Ukraine. It was also proved that the volumes of transportation of goods by rail are closely related to the volumes of production of industrial goods and agricultural products. The volume of goods shipment by rail is characterized by close relationship with the output of production of industrial and agricultural goods. The forecast of departure of coal by rail was developed in the article (as cargo with the highest share in the overall cargo turnover) on the basis of autoregressive model of growth considering economical changes in Ukraine. Taking into account the experience of international countries, ensuring the efficient operation of the rail transport operation is possible only on the basis of developing a forecast of its activities. This will allow to find a reserve for its transportation and throughput. Informational and methodological basis for the article is publications of scientists doing research in the field in question, materials of periodicals and Internet sources. Taking into account the country's production potential for the study of economic development of both rail transport as a whole and its separate lines, including those with low activity, the authors developed a model of economic growth for both the gross domestic product as a whole and for individual branches the current economic structure of Ukraine, especially for rail transport. The quality of available statistical information influences significantly not only the process of parameterization, but also the quality of the model and the results of the whole modelling process. The information on the dynamics of economic features is used. It is represented in the form of time series of indicators. Time series of this economic variable is a sequence of values, measured at regular time intervals during the analyzed period. According to the results, the turnover of Ukrainian railways (including low-intensity lines) will decrease in subsequent years. This is due to a decrease in production in many sectors of the economy. At the same time, the achieved results should be taken into account in the operational model of railways in the future.

Keywords: railway transport, structure of cargo, autocorrelation function, forecast, economic development.

JEL Classification: C46, L92

Formulas: 3; fig.: 7; tabl.: 4; bibl.: 10. 
Кириленко О. М.

д.е.н., дочент,

Наиіональний авіаиійний університет, Україна;

e-mail: ons@ua.fm; ORCID ID: 0000-0003-2406-7050

Разумова К. М.

д.е.н., дочент,

Наиіональний авіаиійний університет, Україна;

e-mail: krazum@ukr.net; ORCID ID: 0000-0001-6385-2823

Новак В. $\boldsymbol{O}$.

к.е.н., професор,

Національний авіаційний університет, Україна;

e-mail:novak.nau@mail.ru; ORCID ID: 0000-0001-6899-2016

Рязановська В. В.

асистент

Національний авіаційний університет, Украйна;

e-mail: ryazanovskaya@ukr.net; ORCID ID: 0000-0003-2680-3306

\section{ПРОГНОЗУВАННЯ ПЕРЕВЕЗЕНЬ ВАНТАЖІВ \\ ЗАЛІЗНИЧНИМ ТРАНСПОРТОМ \\ 3 УРАХУВАННЯМ ЕКОНОМІЧНИХ ЗМІН В УКРАЇНІ}

Анотація. Розроблено прогноз перевезень вугілля залізничним транспортом (як вантажу з найбільшою питомою вагою в структурі перевезень) за допомогою запропонованої автокореляційної моделі зростання, 3 урахуванням економічних змін в Україні. Також доведено, що обсяги перевезень вантажів залізничним транспортом тісно пов'язані 3 обсягами випуску промислових товарів і сільськогосподарської продукції. $У$ статті зроблено прогноз перевезень вугілля залізничним транспортом (як вантажу з найбільшою питомою вагою в структурі перевезень) за допомогою запропонованої автокореляційної моделі зростання, з урахуванням економічних змін в Україні. Враховуючи досвід міжнародних країн, забезпечення ефективного функціонування роботи залізничного транспорту можливе лише на основі розробки прогнозу його діяльності. Це дасть можливість виявити резерв його перевізної та пропускної потужності. Інформаційно-методологічною основою даної статті $\epsilon$ публікації вчених, що проводять дослідження в даній галузі, матеріали періодичних видань та джерела Інтернету. Враховуючи виробничий потенціал країни для вивчення економічного розвитку як залізничного транспорту в цілому, так і окремих його ліній, в тому числі, тих, що мають низький рівень активності, авторами розроблена модель економічного зростання як для валового внутрішнього продукту в цілому, так i для окремих галузей поточної економічної структури України, особливо для залізничного транспорту. Якість доступної статистичної інформації значно впливає не тільки на процес параметризації, але і на якість моделі та результати всього процесу моделювання. В статті використовується інформація про динаміку економічних характеристик, що представлена у вигляді часових рядів показників. Часові ряди цієї економічної змінної є послідовністю значень, виміряних за регулярні часові інтервали протягом аналізованого періоду. Згідно отриманих результатів, вантажообіг українських залізних доріг (включаючи лінії з низькою інтенсивністю) в наступні роки скоротиться. Це зумовлено зменшенням виробництва у багатьох галузях економіки. Одночасно досягнуті результати слід враховувати в макеті операційної діяльності залізниць у майбутньому.

Ключові слова: залізничний транспорт, структура вантажів, автокореляційна модель, прогноз, економічне зростання.

Формул: 3; рис.: 7, табл.: 4, бібл.: 10. 
Кириленко О.Н.

д.э.н., доцент,

Национальный авиационный университет, Украина;

e-mail: ons@ua.fm; ORCID ID: 0000-0003-2406-7050

Разумова Е. $\mathrm{H}$.

д.э.н., доцент,

Национальный авиационный университет, Украина; e-mail: krazum@ukr.net; ORCID ID: 0000-0001-6385-2823

Новак В. $О$.

к.э.н., профессор,

Наџиональный авиачионный университет, Украина; e-mail:novak.nau@mail.ru; ORCID ID: 0000-0001-6899-2016

Рязановська В. В.

асистент,

Национальный авиационный университет, Украина;

e-mail: ryazanovskaya@ukr.net; ORCID ID: 0000-0003-2680-3306

\section{ПРОГНОЗИРОВАНИЕ ПЕРЕВОЗОК ГРУЗОВ НА ЖЕЛЕЗНОДОРОЖНОМ ТРАНСПОРТЕ \\ С УЧЕТОМ ЭКОНОМИЧЕСКИХ ИЗМЕНЕНИЙ В УКРАИНЕ}

Аннотация. Разработан прогноз перевозок угля железнодорожным транспортом (как груза с наибольшим удельным весом в структуре перевозок) с помощью предложенной автокорреляционной модели роста, с учетом экономических изменений в Украине. Также доказано, что объемы перевозок грузов железнодорожным транспортом тесно связаны с объемами выпуска промышленных товаров и сельскохозяйственной продукции. В статье сделан прогноз перевозок угля железнодорожным транспортом (как груза с наибольшим удельным весом в структуре перевозок) с помощью предложенной автокорреляционной модели роста, с учетом экономических изменений в Украине. Учитывая опыт международных стран, обеспечение эффективного функционирования работы железнодорожного транспорта возможно только на основе разработки прогноза его деятельности. Это позволит выявить резерв его перевозочной и пропускной мощности. Информационно-методологической основой данной статьи являются публикации ученых, проводящих исследования в данной области, материалы периодических изданий и источники Интернета. Учитывая производственный потенциал страны для изучения экономического развития как железнодорожного транспорта в целом, так и отдельных его линий, в том числе, имеющих низкий уровень активности, авторами разработана модель экономического роста как для валового внутреннего продукта в целом, так и для отдельных отраслей текущей экономической структуры Украины, особенно для железнодорожного транспорта.

Ключевые слова: железнодорожный транспорт, структура грузов, автокорреляционная модель, прогноз, экономический рост.

Формул: 3; рис.: 7; табл.: 4; библ.: 10.

Introduction. Railways are the priority kind of transport in the transport system of Ukraine. However, its current state does not meet the required standards. It is characterized by imbalance of various activities, lack of efficiency in economic activity and significant level of fixed assets depreciation. At present, the question arises concerning its reorganization especially taking into account the strategic importance of this sector for economic development of the country.

Decision-making on strategic development requires understanding the factors influencing trends and their changes. The profit from economic activity of railway transport is generated through cargo shipments. The main task impacting its further development is the identification of key cargo areas of transportation and possible changes in these flows. 
Changes in GDP cause changes in cargo turnover on transport which should be taken into account.

Actual scientific researches and issues analysis. Informational and methodological basis for the article is publications of scientists doing research in the field in question, materials of periodicals and Internet sources. The most important apparatus for forecasting cargo departure and its turnover on the railway transport is described in the scientific works of E. Aksenov [2012], O. Gnenniy [2013], O. Kyrylenko [2014], K. Razumova [2015].

The research objective. To study (investigate) the structure of the main cargo departures with the aim of forecasting the volumes of transportation service of railway transport, to carry out the forecast of cargos shipment taking into account the turbulent state of the national economy of Ukraine.

The quality of available statistical information influences significantly not only the process of parameterization, but also the quality of the model and the results of the whole modelling process. Realizing the process of forecasting, the information on the dynamics of economic features is used. It is represented in the form of time series of indicators. Time series of this economic variable is a sequence of values, measured at regular time intervals during the analyzed period. Railway transport is a leading transport mode at the market of Ukraine.

Taking into account the production potential for study of economic development, as for railway transport in general, as for separate lines, including those which have low level of activity, there was developed the model of economic growth by the authors, as for gross domestic product in general, as for separate sectors of current economic structure of Ukraine, especially for railway infrastructure.

The statement of basic materials. In terms of turnover, the segment of rail transport in 2017 was $56 \%$, or 191,9 bln ton kilometers [1]. The overall structure of cargo transported by rail is presented in Figure 1. The authors performed the forecast for all types of products, that are transported, but in this article we opt to present only an example of a calculation method using the data on the cargo with the highest rate of transportation - that is coal $(26,8 \%)$.

The authors investigated the main characteristics of national economy of Ukraine, with an annual statistical reporting during 2003-2016 years (GDP, 2016).

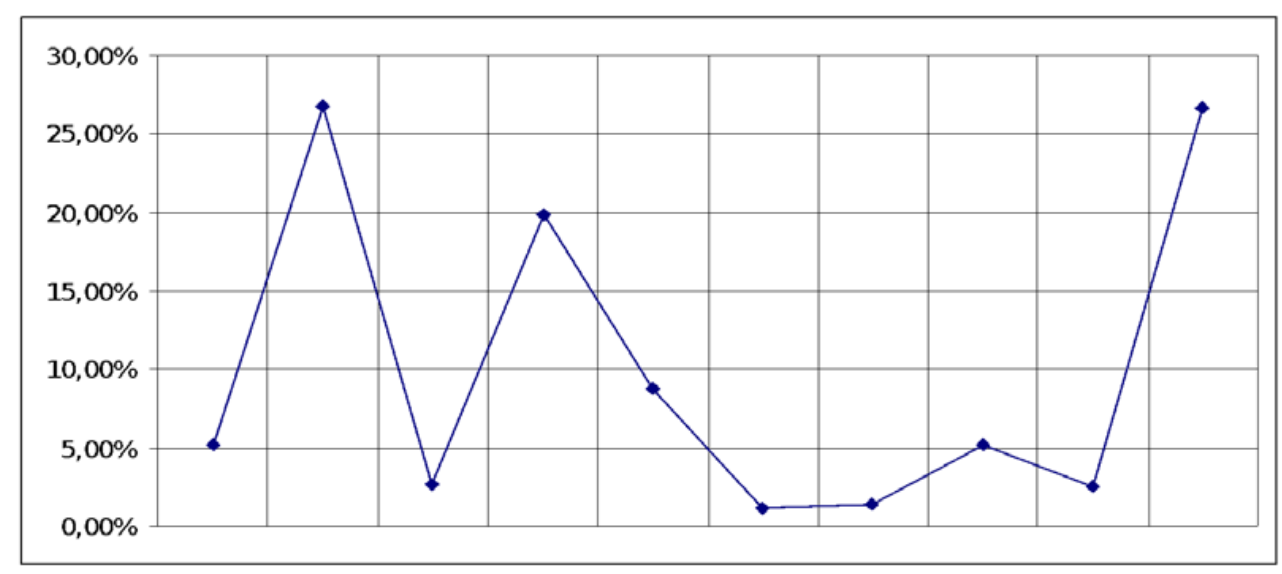

Fig.1. Structure of cargo that was transported by the railway transport in 2016

[Statistical information, 2016]

The volume shipment of goods by rail is characterized by a close relationship between volumes of production of goods in the industry and production of agriculture in Ukraine. The information concerning the volumes of production of the main types of products of national industry and agro - industrial complex is formed on the base of State Statistics Service of Ukraine data (GDP, 2016).

Data about volumes of cargo departure and volumes of production of main types of industrial products and agriculture are given in table 1 . 
Table 1.

Dynamics of cargo departure and production of main types of goods of industry and agro-industrial complex

\begin{tabular}{|c|c|c|c|c|c|}
\hline Year & Departure of cargo, & $\begin{array}{c}\text { Production, } \\
\text { thousand tons }\end{array}$ & \multirow{2}{*}{$\begin{array}{c}\text { Coefficient of } \\
\text { thousand tons }\end{array}$} & \multicolumn{2}{|c|}{ Base index, times } \\
\cline { 5 - 6 } & 363364,8 & 415881 & 0,874 & Departure & Arrival \\
\hline 2003 & 388295,3 & 457713 & 0,848 & 1,069 & 1,101 \\
\hline 2004 & 379926,7 & 455430 & 0,834 & 1,046 & 1,095 \\
\hline 2005 & 398148,3 & 474233 & 0,840 & 1,096 & 1,140 \\
\hline 2006 & 415910,6 & 477133 & 0,872 & 1,145 & 1,147 \\
\hline 2007 & 399679,7 & 465451 & 0,859 & 1,100 & 1,119 \\
\hline 2008 & 322221,8 & 408761 & 0,788 & 0,887 & 0,983 \\
\hline 2009 & 357969,1 & 431856 & 0,829 & 0,985 & 1,038 \\
\hline 2010 & 388715,5 & 486874 & 0,798 & 1,070 & 1,171 \\
\hline 2011 & 378102,2 & 468424 & 0,807 & 1,041 & 1,126 \\
\hline 2012 & 377318,2 & 475318 & 0,794 & 1,038 & 1,143 \\
\hline 2013 & 325100,0 & 424734 & 0,765 & 0,895 & 1,021 \\
\hline 2014 & 315342 & 403277 & 0,782 & 0,861 & 1,011 \\
\hline 2015 & 323474 & 422378 & 0,765 & 0,832 & 0,987 \\
\hline 2016 & & &
\end{tabular}

[systematized by authors]

It is understood from the table 1, that there is a strong interconnection between the volumes of departure of cargo and the volumes of production of main types of industry products and agroindustrial complex, which also shows coefficient of correlation of these indexes, which is equal 0,8415 .

Thus, the forecasted volumes of departure of cargo, as author thinks, can be defines as the product of forecasted general volumes of production of the main types of goods of industry and agro-industrial complex and forecasted coefficients of transportation. To identify trends in time series of coefficients of transportation the autocorrelation functions of output series dynamics and dynamics of growth series are used (figure. 2). Autocorrelation - is a statistical interconnection between sequences of values of one series, taken with a shift, for example, for a random process with a shift of time.

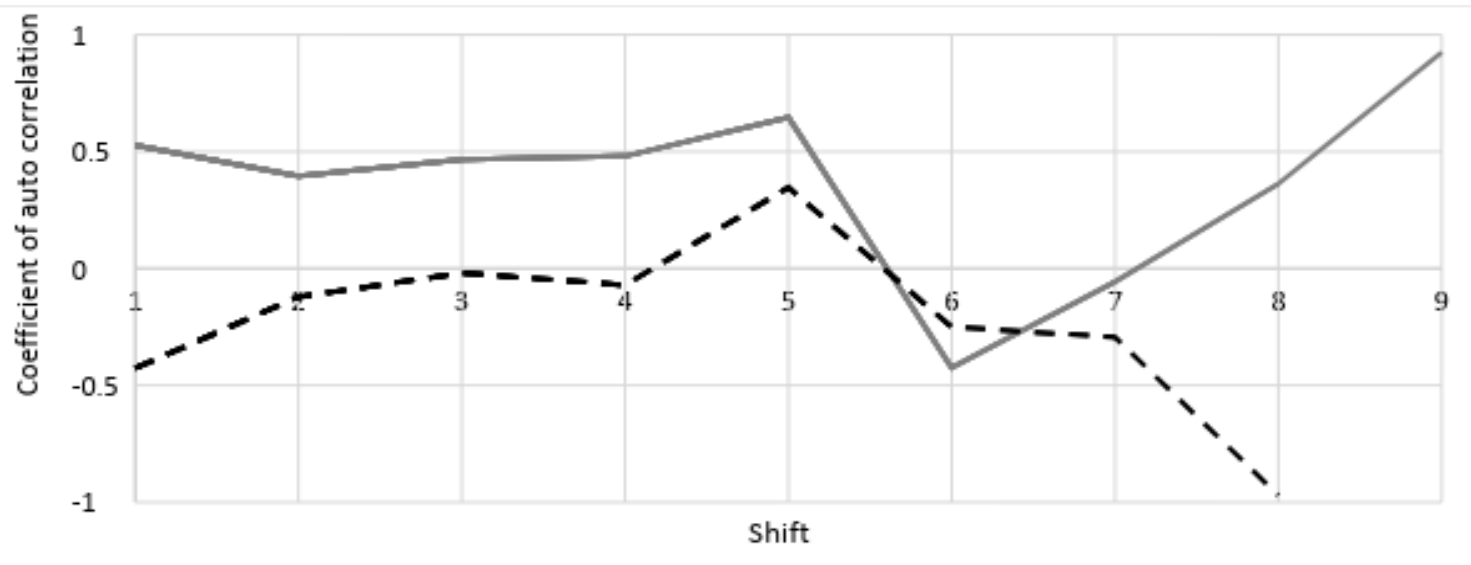

*[Developed by authors]

Fig. 2. Auto correlative functions of transportation coefficients*

From the Figure 2. it is understood, that for forecasting it is advisable to use autoregressive model of growth with shift on 5 years. Using a standard procedures of regressive analysis it is set the parameters of the model

where:

$$
x_{t}=0,5902+0,3981 \cdot x_{t-5},
$$


$x$ - growth of sequence of dynamic coefficients of transportation in a sequence in a corresponding year.

Forecasted coefficients of transportation are identified in table 2.

Table 2.

Forecast of coefficients of transportation*

\begin{tabular}{|c|c|c|c|}
\hline Year & Coefficient of transportationi & $\begin{array}{c}\text { Growth of the coefficient of } \\
\text { transportationi }\end{array}$ & $\begin{array}{c}\text { Growth of the coefficient of } \\
\text { transportationi with shift on } 5 \\
\text { years }\end{array}$ \\
\hline 2018 & 0,732 & 0,9819 & 0,9839 \\
\hline 2019 & 0,713 & 0,9738 & 0,9635 \\
\hline 2020 & 0,707 & 0,9919 & 1,0090 \\
\hline \multicolumn{2}{|c}{} \\
\hline
\end{tabular}

Dynamics and forecast of coefficients of transportation are shown on figure 3. Forecast of the volume of production of main types of production is made by groups.

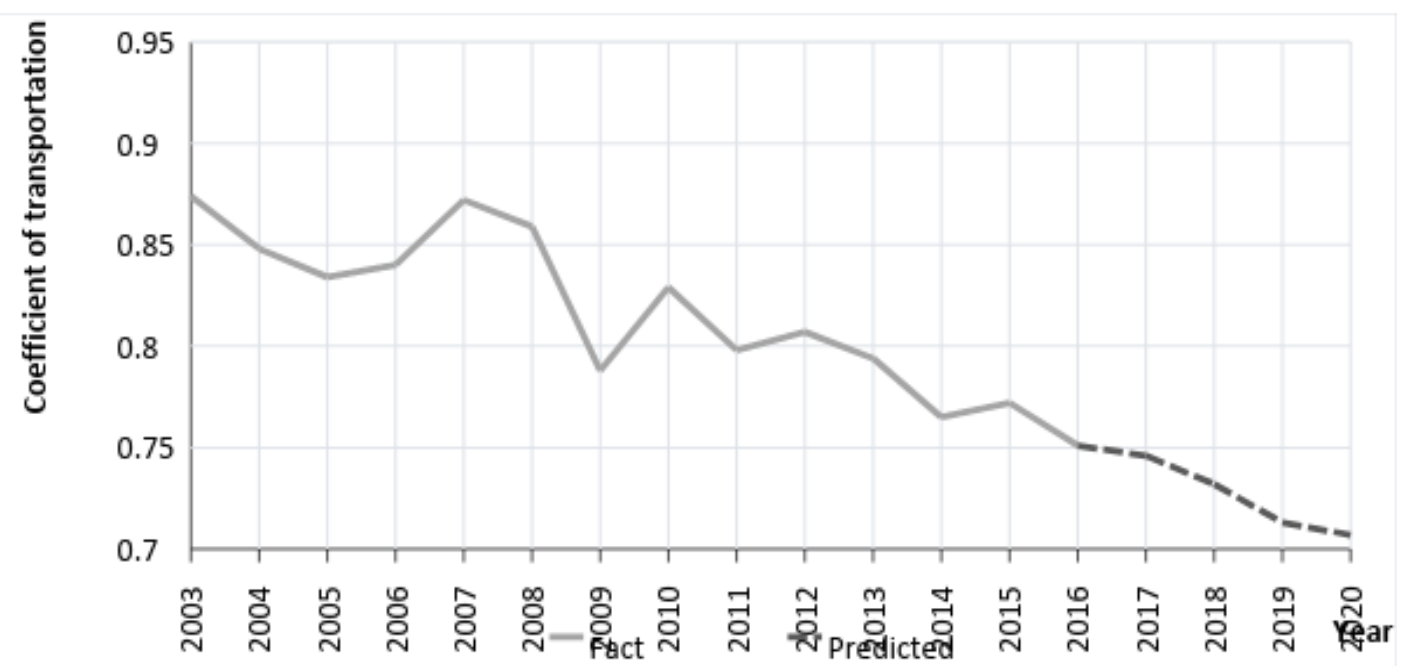

*[Developed by authors]

Fig. 3. The graph of dynamics and forecast of coefficients of transportation*

The information about the volume of production of coal are given in table 3.

Table 3.

Amounts of production of prepared coal, thousand tons*

\begin{tabular}{|c|c|c|c|}
\hline Period & Amounts of production & Period & Amounts of production \\
\hline 1996 & 57000 & 2007 & 58900 \\
\hline 1997 & 58600 & 2008 & 59500 \\
\hline 1998 & 59500 & 2009 & 55000 \\
\hline 1999 & 62800 & 2010 & 55000 \\
\hline 2000 & 62400 & 2011 & 62700 \\
\hline 2001 & 61700 & 2012 & 65700 \\
\hline 2002 & 62000 & 2013 & 64200 \\
\hline 2003 & 59800 & 2014 & 44686 \\
\hline 2004 & 59400 & 2015 & 39760 \\
\hline 2005 & 60400 & 2016 & 40864 \\
\hline 2006 & 61700 & 2017 & 34916 \\
\hline
\end{tabular}

Form the table 3, you can see that amounts of production in 2017 decreased compared to others years. So the forecast of the production amounts in 2018 are based on the results of 2017. For the next periods the forecasts is made by using the difference of the first order, made without considering the 2017 data. The graph of the volume of production is shown on figure 4 . 
On the figure 4, is shown the changing trends of September 2017. So for the next forecast we use trend equation, that was made taking in account August — December 2017 data:

where:

$$
x_{t}=1626+70 \cdot t \text {, }
$$

$\mathrm{x}$ - volume of production of coal for 1 month, thousand tons;

$\mathrm{t}$ - number of the month, starting January 2017

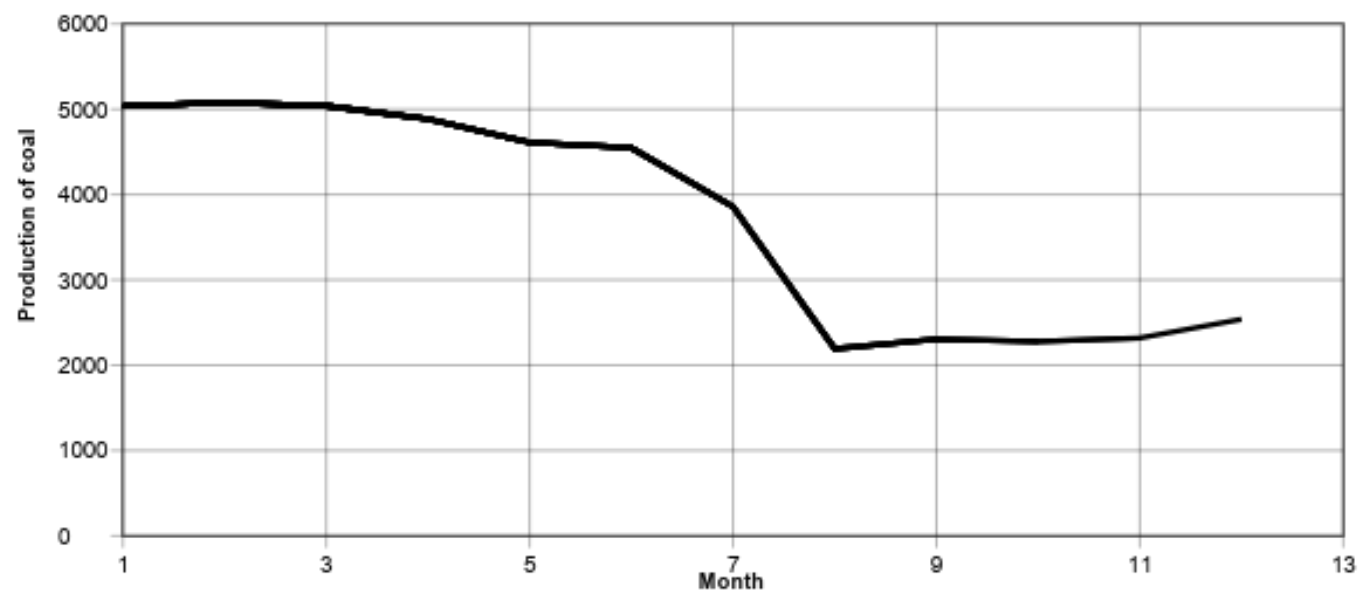

Fig. 4. Graph of volume production of coal 2017*

*[Developed by authors

So the forecast of the volume of production in 2018 is equal:

thousand tons

$$
x_{t}=1626 \cdot 12+70 \cdot \sum_{t=13}^{24} t=35052
$$

To identify trends in time series of volume of coal production the autocorrelation function of the dynamic difference of the first order is used Pic.5. We can see clearly on the figure 5, that for forecast it should be used autoregressive model with the shift increments for 6 years. Using the standard calculation of autoregressive model we got this parameters:

$$
x_{t}=49,2+0,8723 \cdot x_{t-6} \text {, }
$$

where:

$\mathrm{x}$ - rooted volume of coal production for the year, thousand tons

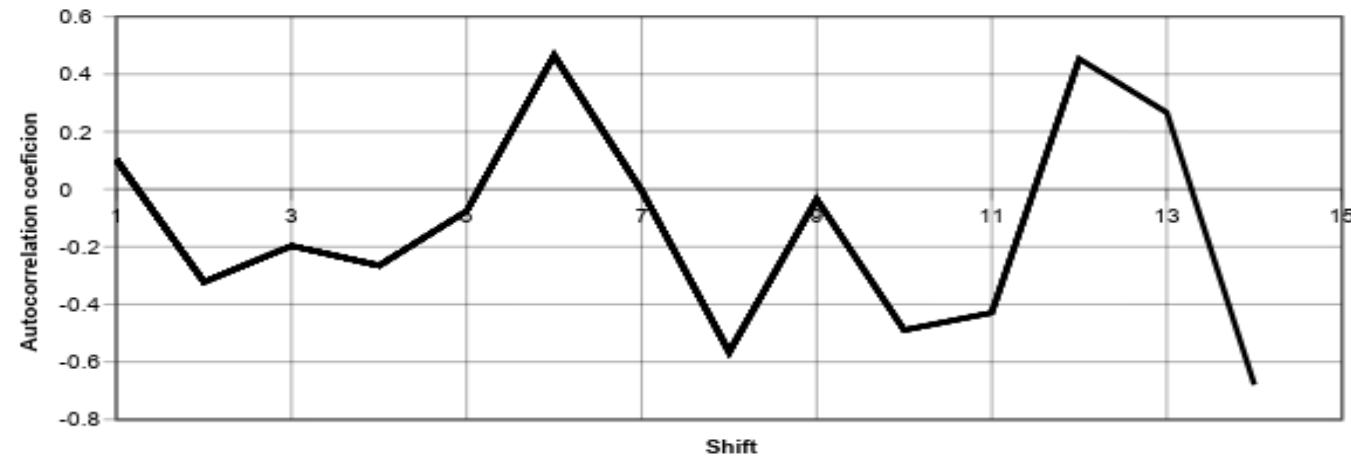

Fig. 5. Autocorrelation function of the dynamic difference of the first order excluding 2017 data* *[Developed by authors]

Using the model (3) the forecast of production decrease in 2018-2020 is determined and it is equal 2668, 1260 and 549 thousand tons.

Thus, forecasted volume of production of coal is

$$
\text { - } \quad \text { In } 2018-41871+2668=4539 \text { thousand tons }
$$


- $\quad$ In $2019-44539+1260=43279$ thousand tons

- $\quad$ In $2010-43279+549=43828$ thousand tons

Dynamics and the forecast of the volume of production of coal is pictured on figure 6 .

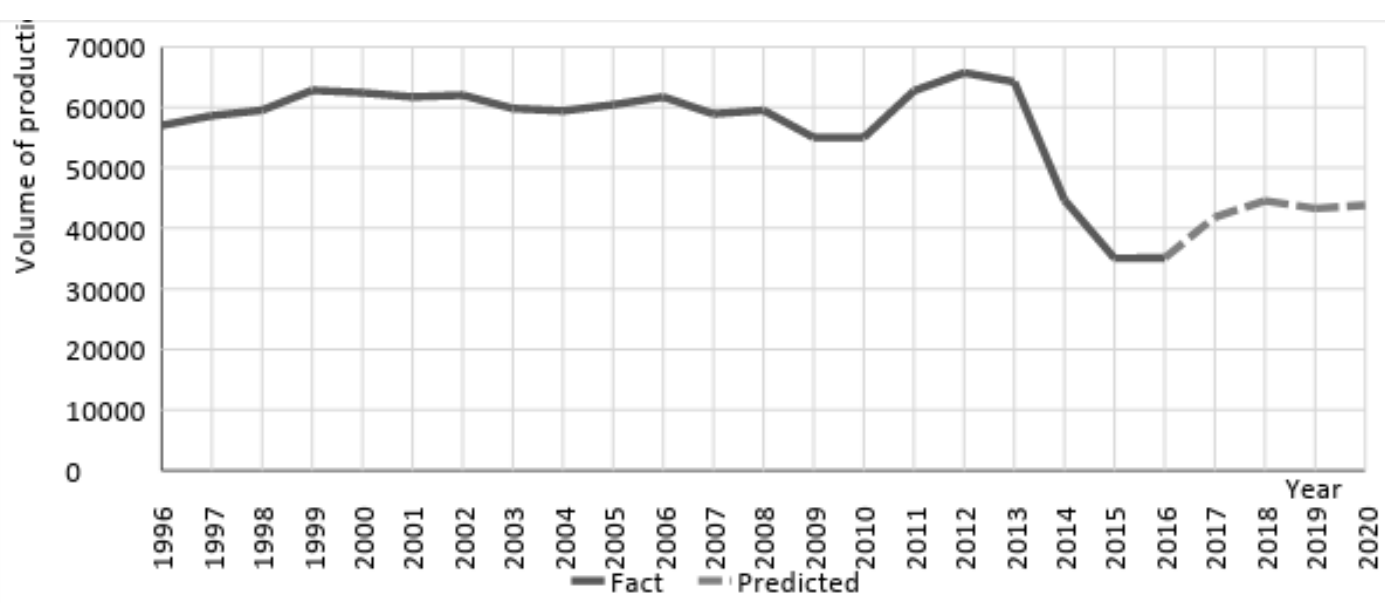

eloped by authors]

So if we take in account the shown method, we can get the forecast not only of the production of coal but also of the main cargo that is transported by the Ukrainian railroad (Chernenko, 2009, Kyrylenko, 2014, Novak, 2012). They are used for calculation of index transportation of cargo with the prospective till 2020. Predicted volumes of transported cargo that is determined by an author, is a sum of predicted volumes of production of the main types of cargo and agroindustrial complex and the coefficient of transportation. As it shown in the table 4. The received dynamic indicators and the prediction of transported cargo are shown on the figure 7.

Prediction of transported cargo, thousand tons*

\begin{tabular}{|c|c|c|c|}
\hline Year & Transported cargo & Coefficient of transportation & $\begin{array}{c}\text { Production of the main kinds of } \\
\text { products }\end{array}$ \\
\hline 2018 & 326808 & 0,732 & 446459 \\
\hline 2019 & 324748 & 0,713 & 455467 \\
\hline 2020 & 320518 & 0,707 & 453350 \\
\hline
\end{tabular}

*[Developed by authors]

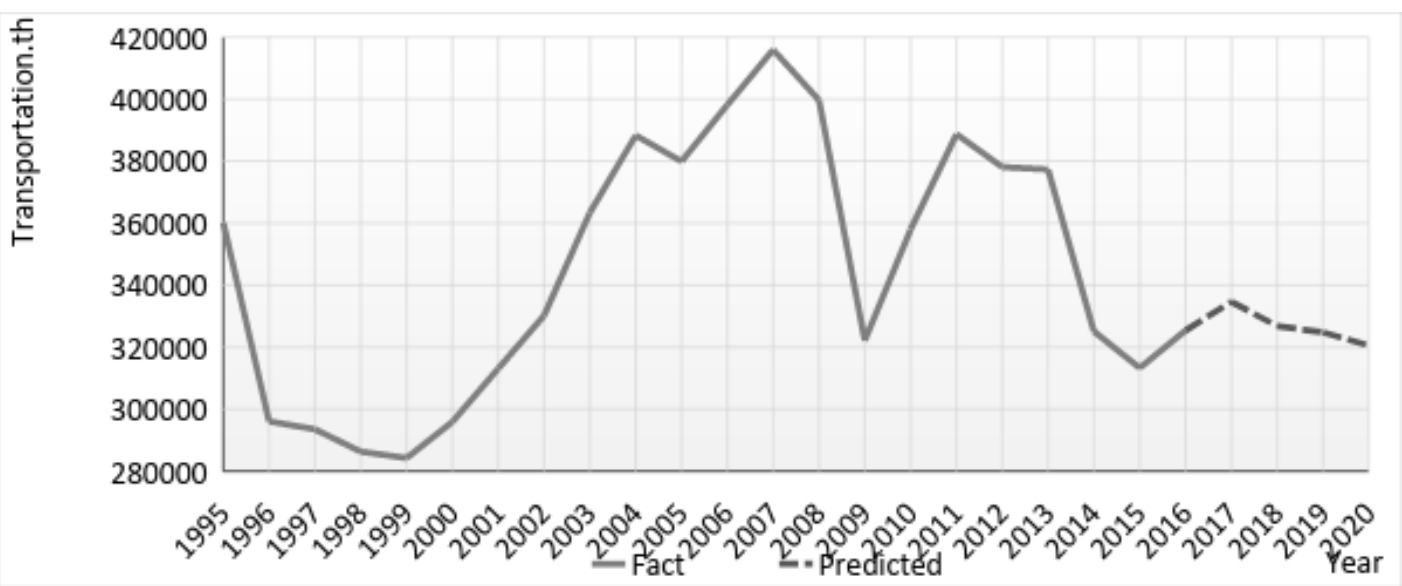

*[Developed by authors]

Fig. 7. Dynamics and forecast of cargo transportation* 
Conclusions. According to obtained results the cargo turnover of Ukrainian railroads will decrease next years (including the lines with low intensity). It is caused by reduced output in many branches of the economy. At the same time achieved findings should be taken into account in the layout of operating activity of railroads in the future.

1. Валовий внутрішній продукт у 2014 р. : статистична інформація [Електронний ресурс] / Державна служба статистики України. — Режим доступу : http://www.ukrstat.gov.ua.

2. Транспорт і зв'язок України у 2014 р. : статистична інформація [Електронний ресурс] / Державна служба статистики України. — Режим доступу : http://www.ukrstat.gov.ua.

3. Аксьонов I. М. Транспортна логістика / І. М. Аксьонов, В. В. Габа, К. М. Шерепа. — Київ : ДЕТУТ, 2012. $202 \mathrm{c}$.

4. Гордієнко I. В. Дослідження моделей взаємодії транспортних потоків [Електронний ресурс] / I. В. Гордієнко // Проблеми системного підходу в економіці. - 2011. - № 1. - Режим доступу: http://www/nbuv.gov.ua/ejournals/PSPE/index.htm.

5. Kyrylenko O. M. Features of functioning railway low-traffic lines: Proceedings of the 12th International Scientific Conference «Modern management problems» / O. M. Kyrylenko. — Kyiv, 2016. — P. 39—40.

6. Новак В. О. Взаємодія аеропорту з транспортними підприємствами: організація та управління : монографія / В. О. Новак, I. В. Гордієнко, О. К. Катерна, В. О. В. Ільєнко. - Київ : НАУ, 2012. - 277 с.

7. Разумова К. М. Системний економічний аналіз у менеджменті пасажирських перевезень : монографія / за ред. К. М. Разумової. - Київ : Кондор-Видавництво, 2014. — 240 с.

8. Razumova E. N. Assessment of competitive positions of the enterprises of passenger transport, taking into account loyalty strategic partners / E. N. Razumova ; Sciences of the National Aviation University «Problems of system approach in Economics». — Kyiv: NAU, 2014. — № 50. — P. 79-82.

9. Гріфін Р. Основи менеджменту : підручник / наук. ред. В. Яцура, Д. Олесневич. — Львів : БаК, 2001. — 624 с. $532 \mathrm{p}$.

10. Vasilenko A. O. Production (operational) management: / A. O. Vasilenko, T. L. Tkachenko. — Kyiv: ZUL, 2003.

Стаття рекомендована до друку 03.09.2018

(C) Кириленко О. М., Разумова К. М., Новак В. О., Рязановська В. В.

\section{References}

1. Derzhavna sluzhba statystyky Ukrainy (n. d.). Valovyi vnutrishnii produkt u 2014 r.: statystychna informatsiia [State Statistics Service of Ukraine. Gross Domestic Product in 2014: Statistical Information]. Retrieved from http://www.ukrstat.gov.ua [in Ukrainian].

2. Derzhavna sluzhba statystyky Ukrainy. (n. d.). Transport i zviazok Ukrainy u 2014 r. : Statystychna informatsiia [State Statistics Service of Ukraine. Transport and Communications of Ukraine in 2014. Statistical Information]. Retrieved from http: http://www.ukrstat.gov.ua [in Ukrainian]. Ukrainian].

3. Aksonov, I. M., Haba, V. V., \& Sherepa, K. M. (2012). Transportna lohistyka [Transport logistics]. Kyiv: DETUT [in

4. Hordiienko, I. V. (2011). Doslidzhennia modelei vzaiemodii transportnykh potokiv [Research of models of interaction of transport streams]. Problemy systemnoho pidkhodu v ekonomitsi - Problems of the system approach in economics, 1 . Retrieved from http://www.nbuv.gov.ua/e-journals/PSPE/index.htm [in Ukrainian].

5. Kyrylenko, O. M. (2016). Features of functioning railway low-traffic lines: Proceedings of the 12th International Scientific Conference «Modern management problems». Kyiv.

6. Novak, V. O., Hordiienko, I. V., Katerna, O. K., Matvieiev, V. V. \& Ilienko, O. V. (2012). Vzaiemodiia aeroportu z transportnymy pidpryiemstvamy: orhanizatsiia ta upravlinnia [Interaction of the airport with transport enterprises: organization and management]. Kyiv: NAU [in Ukrainian].

7. Razumova, K. M. (Ed.). (2014). Systemnyi ekonomichnyi analiz u menedzhmenti pasazhyrskykh perevezen [System economic analysis in passenger transportation management]. Kyiv: Kondor-Vydavnytstvo [in Ukrainian].

8. Razumova, E. N. (2014). Assessment of competitive positions of the enterprises of passenger transport, taking into account loyalty strategic partners. Sciences of the National Aviation University «Problems of system approach in Economics», 50, 79-82. Kyiv: NAU.

9. Hrifin, R., Yatsura V., \& Olesnevych, D. (2001). (Ed.). Osnovy menedzhmentu [Fundamentals of Management]. Lviv: BaK [in Ukrainian].

10. Vasilenko, A. O., \& Tkachenko, T. L. (2003). Production (operational) management. — Kyiv: ZUL.

The article is recommended for printing 03.09.2018 $\quad$ (C) Kyrylenko O. N., Razumova E. N., Novak V. O., Razanovska V. V. 